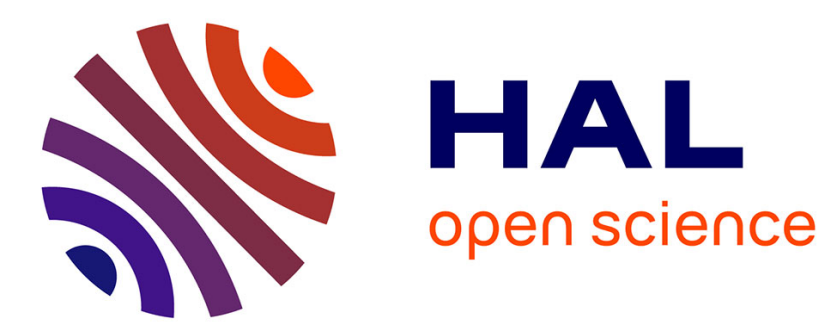

\title{
Processing and properties of SiC-particulate reinforced titanium matrix composites by shock wave consolidation
}

\author{
W. Tong, G. Ravichandran, T. Christman, T. Vreeland
}

\section{To cite this version:}

W. Tong, G. Ravichandran, T. Christman, T. Vreeland. Processing and properties of SiC-particulate reinforced titanium matrix composites by shock wave consolidation. Journal de Physique IV Proceedings, 1994, 04 (C8), pp.C8-331-C8-336. 10.1051/jp4:1994850 . jpa-00253410

\section{HAL Id: jpa-00253410 https://hal.science/jpa-00253410}

Submitted on 1 Jan 1994

HAL is a multi-disciplinary open access archive for the deposit and dissemination of scientific research documents, whether they are published or not. The documents may come from teaching and research institutions in France or abroad, or from public or private research centers.
L'archive ouverte pluridisciplinaire HAL, est destinée au dépôt et à la diffusion de documents scientifiques de niveau recherche, publiés ou non, émanant des établissements d'enseignement et de recherche français ou étrangers, des laboratoires publics ou privés. 


\title{
Processing and properties of SiC-particulate reinforced titanium matrix composites by shock wave consolidation
}

\author{
W. Tong, G. Ravichandran, T. Christman $(1)$ and T. Vreeland Jr \\ Division of Engineering and Applied Science, California Institute of Technology, Pasadena, \\ California 9I125, U.S.A.
}

\begin{abstract}
Résumé: En utilisant la méthode de consolidation par ondes de choc, des compacts de $T i$, renforcés de particules de $\mathrm{SiC}$, sans porosité, et ne présentant ni réaction interfaciale ni fissures macroscopique, ont été obtenus. Un recuit post-compactage approprié à également fait l'objet d'une étude de manière à améliorer la séparation des impuretés et par conséquent la ductilité de la matrice. Des traitements thermiques aditionnels du composite permettent de controler la taille des domaines de réactions interfaciales. Les résultats des tests de comportement mécaniques suggèrent que la bonne ductilité du composite Ti-SiC est conservée pour des domaines de réactions interfaciales minimum $(<0,1 \mu \mathrm{m})$ et qu'un domaine de réactions interfaciales de plus de $0,25 \mu \mathrm{m}$ diminue la ductilité ainsi que la résistance du compact.
\end{abstract}

\begin{abstract}
Using shock wave consolidation, fully dense SiC-particulate reinforced Ti matrix composite compacts that are free from interfacial reactions and macroscopic cracks have been obtained. Proper post-consolidation annealing has been explored to improve impurity segregation and, thus, the ductility of the matrix. Various heat treatments of the composites produce controlled interfacial reaction zone sizes. Results of mechanical testing indicated that good ductility is retained in the $\mathrm{Ti}-\mathrm{SiC}$ composites with a minimum interfacial reaction layer $(<0.1 \mu \mathrm{m})$, while no interface reaction or an interfacial reaction layer of $0.25 \mu \mathrm{m}$ thick or more is detrimental to the tensile ductility and strength of the composites.
\end{abstract}

\section{INTRODUCTION}

The extreme chemical reactivity of titanium provides a major challenge in selecting reinforcement materials and processing techniques for $\mathrm{Ti}$ matrix composite production [1]. While titanium matrix composites offer improved high temperature characteristics compared with aluminum matrix composites, avoiding detrimental interfacial chemical reactions during fabrication of titanium composites is crucial to the material performance. Continuous $\mathrm{SiC}$ fiber-reinforced titanium composites have been sucessfully produced with a 1-5 $\mu \mathrm{m}$ carbon-rich coating on the SiC fibers. Carbon coating is introduced to reduce and control the interfacial reaction during processing and service [2-4]. However, little work exists at present in exploring a similar interface-controlled toughening approach for particulate-reinforced

(1) Present Address: Gillette Corp. R\&D, Gillette Park, Boston, MA 02106-2131, U.S.A. 
titanium matrix composites. The standard processing procedures used in making particulate-reinforced composites, such as casting and hot pressing, often expose the composite to high temperatures for an extended time and are unsuitable for reactive composite systems. Diffusion barriers are difficult to produce on particles and the processing routes used for fiber-reinforcement titanium composite are usually not applicable to $\mathrm{SiC}$ particulate-reinforced titanium MMCs. Loretto and Konitzer [5] reported virtually no ductility and a low tensile strength of SiC particulate reinforced Tị-6Al-4V composites. Their composite compacts made by powder blending and hot pressing are fully dense but have thick reaction zones $(4-5 \mu \mathrm{m})$.

Shock wave consolidation of powders has recently been explored for $\mathrm{SiC}$ particulate reinforced titanium composite by Christman et al. [6] and Tong et al. [7] and $\mathrm{SiC}$ particulate reinforced titanium-aluminide composites by Rhodes et al. [8]. The extremely high pressure and short process time (on the order of a microsecond) achieved during shock consolidation have made it feasible to obtain fully dense compacts with a minimum of interfacial reactions. Here we report our efforts in optimizing the processing procedure for

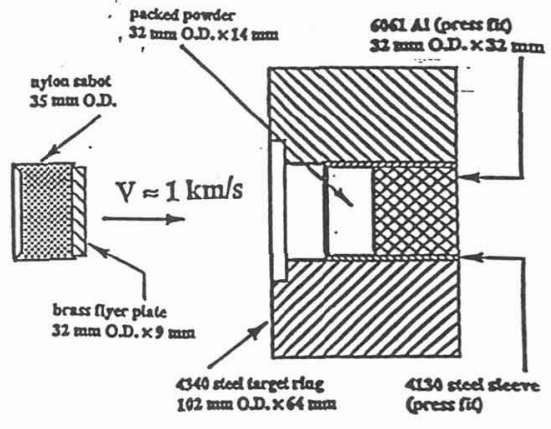

Fig. 1 Schematic of Caltech dynamic compactor. fabrication of $\mathrm{Ti}$-SiC composites through shock wave consolidation and results of mechanical testing of processed composites.

\section{SHOCK WAVE CONSOLIDATION OF TI AND TI-SIC POWDERS}

In our present study, Ti-SiC metal matrix composites were fabricated with the Keck Dynamic Consolidation Facility. A schematic of the target fixture and propellant driven flyer plate assembly is shown in Fig. 1. A $31.5 \mathrm{~mm}$ diameter flyer plate is mounted onto a nylon sabot and accelerated by smokeless shotgun or pistol powder. The densification of the powders is accomplished by the passage of a strong shock wave generated upon the impact of flyer onto the green compact, the target powder [7-10].

Three titanium compacts (\#150, \#155, and \#158) made from three types of unreinforced Ti powders and the three corresponding SiC particle reinforced composite compacts (\#151, \#152, and \#154) were

Table 1 Results of Chemical Analysis of Titanium Powders (weight ppm)

\begin{tabular}{c|c|c|c|c|c|c|c}
\hline Designation & $\mathrm{O}$ & $\mathrm{H}$ & $\mathrm{C}$ & $\mathrm{N}$ & $\mathrm{Fe}$ & $\begin{array}{c}\text { O* }^{*} \\
\text { atomic } \mathrm{ppm}^{\mathrm{c}}\end{array}$ & \multicolumn{1}{c}{ Comments } \\
\hline Type I $^{\mathrm{a}}$ & 1250 & 42 & 189 & 52 & 71 & 465 & $99.9 \%,-100 \mathrm{mesh}$ \\
\hline Type II $^{\mathrm{a}}$ & 1740 & 92 & 159 & 53 & 98 & 602 & $99.5 \%,-325$ mesh \\
\hline Type III $^{\mathrm{a}}$ & 2300 & 17 & 354 & 1500 & 1810 & 1795 & $\begin{array}{l}\text { ball milled Type II powder for } \\
\text { nine hours, -40 mesh }\end{array}$ \\
\hline CP Titanium $^{\mathrm{b}}$ & 1800 & 150 & 1000 & 300 & 2000 & 1035 & $\begin{array}{l}\text { ASTM Grade 1, maximum } \\
\text { impurity limit is listed }\end{array}$ \\
\hline
\end{tabular}

a - Teledyne Wah Chang Laboratories (Albany, Oregon);

b-ASM Metals Handbook [11];

c-Equivalent oxygen concentration [16]. 
obtained free of macroscopic defects. All composite compacts were reinforced with $10 \%$ by volume $\mathrm{SiC}$. The chemical composition of three types of titanium powders is listed in Table 1. Also listed in Table 1 are the maximum impurity limits of commercially pure (CP) ingot processed Ti. A summary of our shock wave consolidation experiments is given in Table 2. The density of each compact was determined using the immersion method of weight measurements in air and toluene. Microhardness measurements were carried out using a Leitz Wetzlar Miniload hardness tester. X-ray diffraction (Inel CPS-120 diffractometer using Co $K \alpha$ radiation, $\lambda=1.7902 \AA$ ) was used to verify the phases in the Ti compact. SEM (CamScan, at $15 \mathrm{keV}$ ) was used to study details of fracture surfaces, Ti-SiC interface zones, and Ti-Ti particle boundaries. 3-mm diameter TEM samples were prepared by ion milling and were examined using a Philips EM430. Specimens were fractured in situ under ultra high vacuum $(<3 x$ $10^{-9}$ Torr) and the freshly created fracture surfaces were rapidly examined by high resolution scanning Auger electron microscopy (Perkin-Elmer).

Elastic moduli of both $\mathrm{Ti}$ and $\mathrm{Ti}-\mathrm{SiC}$ compacts were determined by using the measurements of ultrasonic wave speeds. The compression tests were conducted using an Instron Universal Materials Testing System 4204 at a constant crosshead speed of $0.5 \mathrm{~mm} / \mathrm{min}$ (the resulting strain rate was about $4 \times 10^{-3} \mathrm{~s}^{-1}$ ). Threepoint bending tests were conducted to assess the tensile properties of the compacts. Analysis of linear elasticity and power-law plasticity was used to compute both the maximum stress and strain within the bending specimens (for details, see Tong et al. [7]).

Table 2 Summary of Shock Parameters for Matrix and Composite Compacts

\begin{tabular}{c|c|c|c|c|c|c|l}
\hline $\begin{array}{c}\text { Shot } \\
\text { No. }\end{array}$ & $\begin{array}{c}\text { Flyer } \\
\text { Velocity } \\
(\mathrm{m} / \mathrm{s})\end{array}$ & $\begin{array}{c}\text { Peak } \\
\text { Pressure } \\
(\mathrm{GPa})\end{array}$ & $\begin{array}{c}\text { Shock } \\
\text { Energy } \\
(\mathrm{kJ} / \mathrm{kg})\end{array}$ & $\begin{array}{c}\text { Homogeneous } \\
\text { Temperature } \\
\left({ }^{\circ} \mathrm{C}\right)\end{array}$ & $\begin{array}{c}\text { Initial } \\
\text { Porosity }\end{array}$ & $\begin{array}{c}\text { Powder } \\
\text { Type }\end{array}$ & $\begin{array}{c}\text { Mixing \& } \\
\text { Degassing* }\end{array}$ \\
\hline 150 & 1023 & 4.20 & 407.3 & 689 & 0.4571 & Ti (Type I) & Schedule 1 \\
\hline 151 & 1055 & 4.40 & 432.0 & 723 & 0.4600 & $\begin{array}{l}\text { Ti (Type I) + } \\
\mathrm{SiC}(\# 600)\end{array}$ & Schedule 1 \\
\hline 155 & 939 & 3.42 & 356.2 & 617 & 0.4753 & $\mathrm{Ti}$ (Type II) & Schedule 1 \\
\hline 152 & 1095 & 4.61 & 464.5 & 766 & 0.4664 & $\begin{array}{l}\mathrm{Ti} \text { (Type II) } \\
+ \text { SiC (\#600) }\end{array}$ & Schedule 1 \\
\hline 158 & 978 & 4.11 & 369.6 & 636 & 0.4382 & $\mathrm{Ti}$ (Type III) & Schedule 2 \\
\hline 154 & 963 & 4.07 & 357.6 & 619 & 0.4328 & $\begin{array}{l}\text { Ti (Type III) } \\
+ \text { SiC (\#600) }\end{array}$ & Schedule 2 \\
\hline
\end{tabular}

* Powder mixing and pre-compaction degassing schedules:

1. wet mixing in toluene, vacuum outgassing at $600^{\circ} \mathrm{C}$ for 6 hours;

2. ball milling for 9 hours in argon-filled vial, vacuum outgassing at $600^{\circ} \mathrm{C}$ for 12 hours. 


\section{EXPERIMENTAL RESULTS}

\subsection{Unreinforced Titanium Compacts}

Typical results of mid-point deflection versus load in three-point bending tests are shown in Fig. 2 (A) for titanium compacts. For as-consolidated compacts, all bending specimens broke in the linear region which indicated a brittle type failure. An SEM observation of the fracture surface of the as-consolidated compact \#150 indicated that the fracture occurred along the particle-particle boundaries in the bending specimen. Shock wave consolidated titanium and stainless steel compacts obtained by others have also shown very little tensile ductility in the as-consolidated state [12-13]. Failure at the particle-particle boundaries in bending tests indicates a weak and brittle bonding between particles. Brittleness and low strength of particle-particle boundaries are due to the localized deformation and the concentration of contaminants (i.e., such as oxides and other impurities) around particle surfaces. To improve the ductility of shock consolidated compacts, proper annealing should thus be selected to reduce or eliminate prior particle-particle. boundary effects in the compacts and to diffuse surface contaminants into particle interiors [14-15]. Annealed specimens of Ti compacts \#150 and \#155 indeed deformed plastically up to a maximum plastic strain of at least $10 \%$ without failure in bending tests (see Fig. 2A).

\subsection{Ti-SiC Composites}

No apparent reaction layer was observed at the $\mathrm{Ti}-\mathrm{SiC}$ interface in any as-consolidated composite compacts using SEM and TEM. Some results of three-point bending tests for as-consolidated and annealed composite compacts are shown in Fig. 2 (B). The effects of interfacial reaction layers on the compressive and tensile properties of Ti-SiC composites are illustrated in Figs. 3 (A) and (B). As shown in Fig. 3 (A), the compressive strength of $\mathrm{Ti}$-SiC composites increases with increasing annealing temperature (i.e. with interfacial reaction zone size). For specimens annealed at $850^{\circ} \mathrm{C}$ and $950^{\circ} \mathrm{C}$, specimen cracking was visible at a compressive strain of $0.3-0.4$ which indicated a somewhat less ductile
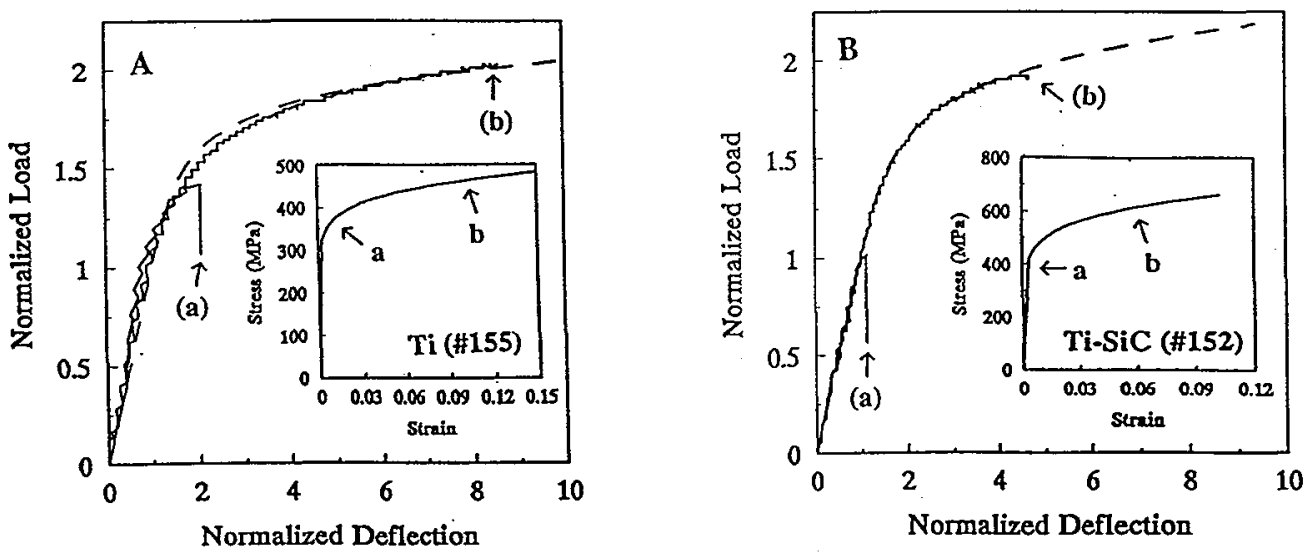

Fig. 2 Results of bending tests of as-consolidated (a) and annealed (b) specimens made from Ti compact \#155 (A) and Ti-SiC compact \#152 (B). The specimen was annealed at $650^{\circ} \mathrm{C}$ for 45 hours in vacuum. The load is normalized by the elastic limit load and the deflection is normalized by the corresponding elastic limit. Solid line - experimental; dashed line analytical. The insert is the elastic-plastic stress-strain curve of $\mathrm{Ti}$ and $\mathrm{Ti}-\mathrm{SiC}$ from the bending test. 
titanium matrix. On the other hand, any significant amount of interfacial reaction (say $x \geq 0.25 \mu \mathrm{m}$ ) in Ti-SiC composites degraded their tensile ductility, as shown in Fig. 3 (B). Virtually zero ductility was observed for as-consolidated samples (brittle Ti particle-particle boundaries and weak bonding between $\mathrm{Ti}$ and $\mathrm{SiC}$ particles) and annealed at $950^{\circ} \mathrm{C}$ for two hours (heavily reacted SiC particles). Plastic yielding was observed for samples annealed at $750^{\circ} \mathrm{C}$ and $850^{\circ} \mathrm{C}$ for two hours but their tensile ductility was still very poor $(\leq 1 \%)$. Good ductility $(>5 \%)$ was obtained only for the sample annealed at $650^{\circ} \mathrm{C}$ for 45 hours in which only a minimum of interfacial reaction occurred $(x \leq 0.1 \mu \mathrm{m})$ and the impurities around titanium particles were fairly well diffused.

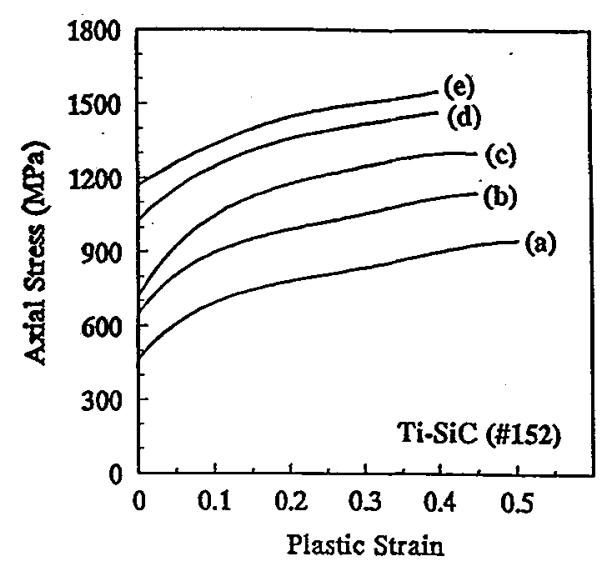

A

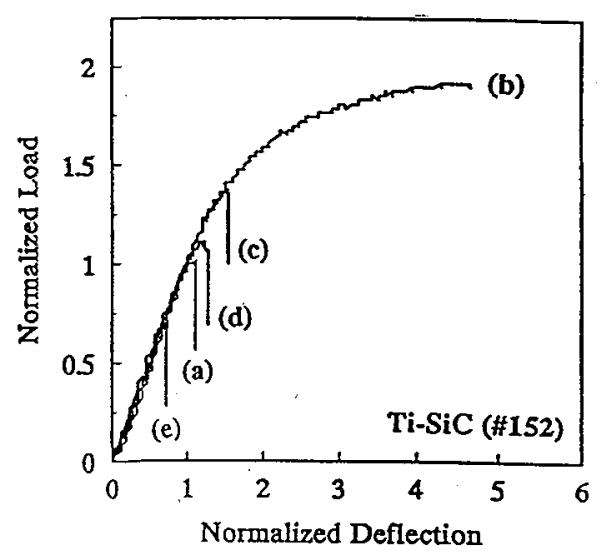

B

Fig. 3 Results of compression tests (A) and bending tests (B) of the Ti-SiC compact (\#152) with a range of interfacial reaction zone thickness, $x$ : (a) as-consolidated $(x \approx$ $0 \mu \mathrm{m})$; (b) annealed at $650^{\circ} \mathrm{C}$ for 45 hours $(x \approx 0.05-0.1 \mu \mathrm{m})$; (c) annealed at $750^{\circ} \mathrm{C}$ for two hours $(x \approx 0.25-0.35 \mu \mathrm{m})$; (d) annealed at $850^{\circ} \mathrm{C}$ for two hours $(x \approx 0.85 \mu \mathrm{m})$; (e) annealed at $950^{\circ} \mathrm{C}$ for two hours $(x \approx 3.9 \mu \mathrm{m})$.

\section{CONCLUSIONS}

Shock wave consolidation has proved to be an effective technique to process SiC-particulate reinforced titanium metal matrix composites with $100 \%$ theoretical density, little or no interfacial reaction and free of macroscopic defects. Elimination of prior titanium particle-particle boundary effects in asconsolidated compacts by proper post-consolidation annealing results in a significant increase in tensile strength and ductility of both titanium and its composite compacts. Microcracking of large SiC particles during consolidation results in elastic moduli of composites lower than theoretical estimates. A ballmilling process is used to reduce the size of SiC particles, the resulting composites have elastic constants which are comparable to theoretical predictions. In comparison with the compacts made of regularly mixed powders, the yield strength of both titanium and its composites made of ball-milled powders is much higher. The ductility of the composite compact made by ball-milled powders, however, is very limited in both compression and bending tests. This brittle behavior is due to a much higher level of impurities (especially $\mathrm{N}$ and $\mathrm{O}$ ) induced during ball-milling. Improved mechanical properties could be obtained by processing composite compacts using regularly mixed micron-size SiC and titanium powders. 
Properly annealed $10 \%$ volume fraction SiC particulate reinforced titanium composites (\#151 and \#152) made of as-received powders show improved tensile strength over that of unreinforced Ti matrix while their tensile ductility remains excellent ( $>5 \%$ ). In comparison, heavily reacted SiC reinforced titanium composites show degraded tensile strength and poor ductility $(\approx 0.16 \%)$ as reported by Loretto and Konitzer [5]. Interfacial reaction zone sizes from a fraction of a micron to several microns have been obtained for shock wave consolidated Ti-SiC composites by further post-consolidation annealing and the interfacial reaction rate is consistent with those reported in the literature [17-20]. Our results of mechanical testing indicated that good ductility is retained in $\mathrm{SiC}$ particulate-reinforced $\mathrm{Ti}$ metal matrix composites with a minimum interfacial reaction layer $(<0.1 \mu \mathrm{m})$, and an interfacial reaction layer of 0.25 $\mu \mathrm{m}$ thick or more due to the reaction is detrimental to the tensile ductility and strength of the composites.

\section{ACKNOWLEDGMENTS}

We would like to acknowledge the support of this research by the Division of Materials Research of the National Science Foundation through grant No. DMR-9116570, Program Director: Dr. B. MacDonald. We would like to thank Mr. Mohit Jain and Ms. Karina Montilla for their help during the experiments and mechanical characterization of the compacts.

\section{REFERENCES}

[1] Loretto M.H. and Johnson T.P., J. Microscopy 169 (1993) 131-138.

[2] Whatley W.J. and Wawner F.E., J.Mater. Sci. Lett. 4 (1985) 173-175.

[3] Wei W., J. Mat. Sci. 27 (1992) 1801-1810.

[4] Warrier S.G. and Lin R.Y., JOM 45 (1993) 24-27.

[5] Loretto M.H. and Konitzer D.G., Met. Trans. 21A (1990) 1579-1587.

[6] Christman T. et al., Scripta Metall. et Mater. 25 (1991) 631-636.

[7] Tong W. et al., submitted to Acta Metall. Mater. (1993).

[8] Rhodes D. et al., Metall. Träs. 21A (1990) 1589-1594.

[9] Gourdin W.H., Prog. Mater. Sci. 30 (1986) 39-80.

[10] Schwartz R.B. et al., Acta Metall. 32 (1984) 1243-1255.

[11] ASM Metals Handbook (American Society for Metals, Metals Park, Ohio, 1980, 3) p.374.

[12] Chiba A. et al., Scripta Metall. 22 (1988) 213-217.

[13] Wright R.N. et al., Metall. Trans. 20A (1989) 2449-2457.

[14] Nakajima H. and Koiwa M., ISIJ-International 31 (1991) 757-766.

[15] Takahashi Y. et al., J. Mat. Sci. 27 (1992) 485-498.

[16] Okazaki K. and Conrad H., Acta Metall. 21 (1973) 1117-1138.

[17] Snide J.A., AFML Report No. AFML-TR-67-354 (1968).

[18] Klein M.J. et al., AFML Report No. AFML-TR-69-242 (1969).

[19] Chamberlain M.B., Thin Solid Films 72 (1980) 305-309.

[20] Martineau M. et al., J. Mat. Sci. 19 (1984) 2749-2761. 